\title{
What Matters In Economics Teaching And Learning? A Case Study Of An Introductory Macroeconomics Course In South Africa
}

J. D. Snowball, (E-mail: j.snowball@ru.ac.za), Rhodes University, South Africa

M. K. Wilson, (E-mail: m.wilson@ru.ac.za), Rhodes University, South Africa

\begin{abstract}
In many universities, economics lecturers now face the challenge of dealing with large, diverse classes, especially at undergraduate level. A common concern is the non-attendance at lectures of unmotivated (conscript) students. Poor lecture quality, as reflected in student evaluations of teaching (SETs), is often blamed for lack of attendance and consequent poor performance. This paper presents the results of a student assessment of a macroeconomics 1 course, coupled with a self-assessment of their own input into the course. The results obtained, using econometric models, suggest that students inputs and attitudes to the course are equally, or more, important than lecture attendance itself.
\end{abstract}

\section{INTRODUCTION}

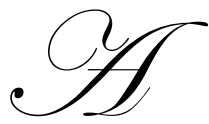

lthough student evaluations of teaching (SETs) are mandatory in most universities, they are a more contentious teaching evaluation tool than many realize. For example, it has been noted by a number of authors that SETs are positively correlated with student characteristics, like grades or expected grades, student effort and even psychological factors. It is thus likely that SETs are capturing, not only the quality of the lectures delivered, but also the characteristics of the specific student.

For example, dedicated students, who attend lectures more regularly, do the required reading and so on, are likely to get more out of lectures than less dedicated students. SETs would then be dependent not only on the actual quality of the lectures, but also on student inputs into the course. The central question would then become how one motivates students to become more involved (lecture quality obviously being part of this), rather than placing the onus on lecturers to improve lecture quality only.

We argue that this new focus, or restatement of the problem, is important because it puts at least, some of the responsibility for learning back with the students. A danger of using SETs for staff evaluation is that some students somehow get the idea that their learning is the lecturer's responsibility and that failure is not their problem, but the result of poor teaching. While teaching quality (as evaluated by the students) is likely to be an important determinant of both lecture attendance and performance, we hypothesize that the causality runs, at least partly, from good students to good lecturer evaluations and not the other way around. Building on this, we hypothesize that student rating of lecture quality is positively related to student input into the course (measured by hours of work outside class, textbook reading and so on), which in turn is often positively related to performance.

\section{CONCLUSIONS AND RECOMMENDATIONS}

What the above discussion indicates is that, while student evaluations of lecture quality is an important determinant of student performance and has a significant effect on their overall rating of the course, it is also capturing some of the characteristics of the students themselves. What seems to be an equally important factor is the motivation of the students, as evidenced by their input into the course. 
The recent focus of higher education research and authorities on assessment methods as being very important in motivating and empowering students may be of considerably help here. For example, peer assessment has been shown to be very useful: it simulates a real-world environment where feedback from peers is important; develops critical evaluation skills; exposes students to a variety of different answers; encourages better quality work; and increases student confidence (Rust 2001; Salemi et al. 2001; Crocket and Vasanthi 2003; Mento and Larson 2004, Race, 2001). While not the focus of this paper, it would be interesting to compare the performance and teaching evaluations of courses taught with and without the use of peer assessment for some tasks. Further research is needed in this area.

We have argued that lecture quality (as evaluated by students) is only one factor influencing course performance and that the evaluations themselves are coloured by student specific characteristics. In line with learnercentered rather than teacher-centered teaching philosophies, we suggest that it is at least equally important that students are motivated to take responsibility for their own learning as it is to get staff to improve lecture quality.

\section{NOTE}

Full paper available from author.

\section{REFERENCES}

1. Anderson, G., Benjamin, D. and fuss, M. 1994 The determinants of success in university introductory economics courses. Journal of Economic Education Spring, 99-119.

2. Becker, W. E. 1997 Teaching Economics to Undergraduates. Journal of Economic Literature 35, 1347-1373.

3. Benedict, M. and Hoag, J. 2004 Seating location in large lectures: Are seating preferences or location related to course performance? Journal of Economic Education Summer, 215-231.

4. Bosshardt, W. and Watts, M. 2001 Comparing student and instructor evaluations of teaching. Journal of Economic Education Winter, 3-17.

5. Crockett, G. and Peter, V. 2003 Extended case study: Peer assessment in a second year macroeconomics unit. Learning and Teaching support network: Generic centre

6. DeCanio, S. 1986 Student evaluations of teaching - a multinomial logit approach. Journal of Economic Education Summer, 165-176.

7. Edwards, L. 2000 An econometric evaluation of academic development programs in economics. South African Journal of Economics 68(3),

8. Gramlich, E. and Greenlee, G. 1993 Measuring teaching performance. Journal of Economic Education Winter,3-13.

9. Grimes, P., Millea, M. and Woodruff, T. 2004 Grades - who's to blame? Student evaluations of teaching and locus of control. Journal of Economic Education Spring, 129-147.

10. Guest, R. and Vecchio, N. 2003 Are there learning spillovers in introductory macroeconomics? International Review of Economics Education 1(1),36-60.

11. Irwin, P., Euvrard, G., Radloff, S. and Boughey, C. (2001) Why go to lectures? Study commissioned for the Vice-Chancellor of Rhodes University

12. Isley, P and Singh, H. 2005 Do higher grades lead to favorable student evaluations? Journal of Economic Education Winter, 29-42.

13. Mento, A. and Larson, J. 2004 Epiphany: A story of improving teaching effectiveness in an executive MBA economics course. Journal of Executive Education Spring, 17-36.

14. Race, P. 2001 A briefing on self, peer and group assessment Generic Centre: Learning and Teaching Support Network

15. Rust, C. 2001 A briefing on assessment of large groups. Learning and_Teaching support network: Generic centre, Assessment series no. 12

16. Selemi, M, Siegfried, J., Sosin, K, Walstad, W. and Watts, M. 2001 Research in economic education: Five new Initiatives The American Economic Review 91(2),445.

17. Seiver, D. 1983 Evaluations and grades: A simultaneous framework. Journal of Economic Education Summer,32-38 
18. Siegfried, J. and Fels, R. 1979. Research on teaching college economics: A survey. Journal of Economic Literature 17, 923-969

19. Stratton, R., Myers, S. and King, R. 1994 Faculty behaviour, grades and student evaluations. Winter,5-15.

20. Van Waalbeek, C. 2004 Does lecture attendance matter? Some observations from a first-year economics course at the University of Cape Town. The South African Journal of Economics: 72(4),861-883. 